\title{
Ebeveyn ve Öğretmen Algılarına Göre Covid-19 Pandemisinin Erken Çocukluk Dönemine Yansımaları: Bir Meta-Sentez Çalışması ${ }^{1}$
}

\section{Reflections of the Covid-19 Pandemic on Early Childhood According to Parents and Teacher Perceptions: A Meta-Synthesis Study}

\author{
Esra AKGÜLiD, Arş. Gör., Hacettepe Üniversitesi, Eğitim Fakültesi, esrak.gul06@gmail.com
}

Gözde ÖZENÇ IRA®D, Arş. Gör., Hacettepe Üniversitesi, Eğitim Fakültesi, gozdeozenc@gmail.com

\begin{abstract}
Akgül, E. ve Özenç-İra, G. (2021). Ebeveyn ve öğretmen algılarına göre Covid-19 pandemisinin erken çocukluk dönemine yansımaları: Bir meta-sentez çalışması. Batı Anadolu Eğitim Bilimleri Dergisi, 12(2), 536-557.
\end{abstract}

Öz. Bu araştırmanın amacı, 0-8 yaş grubundaki çocukların ebeveynlerinin ve öğretmenlerinin bakış açısından Covid-19 pandemisinin erken çocukluk dönemine nasıl yansıdığına ilişkin bilgileri bütünleştirmektir. Bu araştırmada meta-sentez yöntemi kullanıımıştır. Dergipark, ERIC, Web of Science, SAGE Journals, Scopus veritabanları taranmıştır. Aramalarda kullanılan anahtar sözcükler "erken çocukluk, çocuk, sıfır-sekiz yaş, Covid19, pandemi, ilkokul, öğrenci, ebeveyn, aile"dir. Araştırmanın ölçütleri erken çocuklukta Covid-19 pandemisine ilişkin ebeveyn ve öğretmen algılarına odaklanan, 2020-2021 yılları arasında eğitim ve eğitim araştırmaları kapsamında taranan, katılımcıları Türkiye'de olan, nitel metodolojileri kullanan ve tam metnine ulaşılan uygulamalı makaleler incelemeye dâhil edilmiştir. Makaleler Türkçe veya İngilizce dillerinde yazılmış ve hakemli bilimsel dergilerde yayınlanmış olmalıdır. Dâhil etme ve hariç tutma kriterleri göz önüne alınarak yapılan eleme sonucunda 15 makale analiz edilmiştir. Bulgular; bilişsel süreçler, fiziksel durum, duyuşsal durum, toplumsalık ve eğitsel süreçler olmak üzere beş ana kategori altında toplanmıştır. Pandemi çocukların yaşantısını radikal biçimde değiştirmiştir. Evde kalmayla ilişkili olarak azalan fiziksel aktivite ve artan ekran süresi çocukların kilo almasına ve fiziksel görünümlerinin değişmesine neden olmuştur. Bazı çocukların pandemi sürecinde duygu durumları değişmiştir. Pandeminin çocuklar için negatif etkilerini hafifletmek için çocukları ev ve okul ortamında destekleyen yaklaşımların geliştirilmesi gerekmektedir. Araştırma sonunda eğitimcilere, ebeveynlere ve politika yapıcılarına yönelik öneriler sunulmuştur.

Anahtar Kelimeler: Pandemi, Covid-19, Erken çocukluk, Eğitim, Meta-sentez.

Abstract. The aim of this study is to integrate information about how the Covid 19 pandemic affects early childhood from the perspective of parents and teachers of children aged 0-8 years. This study was conducted using the meta-synthesis method. It was searched in the databases Dergipark, ERIC, Web of Science, SAGE Journals and Scopus. The keywords used in the search were "early childhood, child, age zero to eight years, Covid-19, pandemic, elementary school, student, parent, family". Empirical studies that addressed parents' and teachers' perceptions of the Covid-19 pandemic in early childhood, that were conducted between 2020-2021, that were scanned as part of educational research, that had study participants in Turkey, that used qualitative methods, and that reached full text were included in the meta-synthesis. The articles had to be written in Turkish or English and published in peer-reviewed scientific journals. After considering the inclusion and exclusion criteria, 15 articles were fully read and analyzed. The results were subsumed under five main

\footnotetext{
${ }^{1}$ Bu makale, Dokuz Eylül Üniversitesi Eğitim Bilimleri Enstitüsü tarafından düzenlenen “Pandemiler ve Doğal Afetlerde Eğitim" lisansüstü öğrencileri bilimsel makale yarışmasında üçüncü olmuştur.
} 
categories: cognitive processes, physical state, affective state, sociability, and educational processes. The pandemic radically changed children's lives. Decreased physical activity and increased screen time associated with staying at home caused children to gain weight, which altered their physical appearance. The emotional state of some children changed. To mitigate the negative consequences of the pandemic on children, different approaches should be developed and children should be supported in the home and school environment. Recommendations for educators, parents and policy makers were presented as a result of the study.

Keywords: Pandemic, Covid-19, Early childhood, Education, Meta-synthesis. 


\section{Extended Abstract}

Introduction. Globally, government actions related to the pandemic (e.g., school closures and social distancing) have affected millions of children and their families. Although children were not at the forefront in terms of the risk of disease infection and transmission (Gudbjartsson et al. 2020), the indirect effects of the pandemic on children are so crucial that they should not be underestimated. In this context, children experienced significant disruption to their daily routines, both at home and in the family and in early childhood education and care (Barlett, Griffin, and Thomson 2020; OECD 2020). Schools, learning centers, and entire institutions that provided early childhood care services closed their doors and switched to distance teaching (Kim, 2020). Children were deprived of the opportunities for social interaction that the various early childhood education programs offered (Long, 2020). The pandemic had multiple impacts on children's lives. Addressing these experiences in the context of early childhood may contribute to a better understanding of how young children build resilience.

Method. The meta-synthesis method was used in this study. The literature search included the databases of Dergipark, ERIC, Web of Science, SAGE Journals, and Scopus. Empirical studies that focused on parents' and teachers' perceptions of the pandemic in early childhood, were conducted between 2020 and 2021, were examined in the context of education and educational research, and used qualitative methods were included in the review. Articles should have been written in Turkish or English and published in peer-reviewed scientific journals. As a result of screening based on the inclusion and exclusion criteria, 15 articles were included in the meta-synthesis.

Results. The results were subsumed under five main categories: cognitive processes, physical state, affective state, sociability, and educational processes. In this study, it was revealed that the children developed a sense of the pandemic by asking questions about the definition, symptoms, and precautions. The children conceptualized the concepts of pandemic as virus, contagious and harmful and reported that pandemic is a significant threat to health. However, some very young children are not aware of this process. According to Piaget's (1972) cognitive development, this situation can be explained by the fact that children aged 2-6 years are in the preoperational stage. In the preoperational stage, children cannot yet establish the relationship between the part and the whole (Kol, 2011). Therefore, very young children cannot yet comprehend the phenomenon of pandemic.

It has been observed that some children have health problems caused by the pandemic. Decreased physical activity and increased screen time associated with staying at home have caused children to gain weight, which has altered their physical appearance. Increased inactivity due to low physical activity and excessive screen use can trigger many health-related problems, including psychosocial well-being (Hinkley, Brown, Carson, and Teychenne, 2018).

The most significant impact of the pandemic on early childhood in the context of sociality was the use of technology. In the studies reviewed, it was frequently found that the use of technological tools such as phones, tablets, and televisions increased among young children. The American Academy of Pediatrics states that children under the age of two should never sit in front of a screen and limits this time to one hour for children between the ages of two and five (Council on Communications and Media, 2016).

Discussion and Conclusion. The pandemic has led to radical changes around the world and in education. Educational technologies, instructional design in distance education, measurement and assessment, digital data and ethics, new roles in education, digital literacy and digital skills, digital transformation, digital divide, social justice, trauma and anxiety, understanding how education is 
structured by the new world order, and empathy pedagogy, supportive communities and mechanisms, it is clear that reforms are needed (Bozkurt, 2020).

In summary, the meaning of the pandemic varied depending on the age group of the children and how it was explained to them. There are changes in diet and cleaning, sports and exercise habits and accordingly physical appearance. During the course of the pandemic, the emotional state of the children was often highlighted. The emotional state of some children changed and the main factor that caused this difference was that the children's social and emotional needs were met by their parents at different levels. The children often expressed their feelings during the epidemic in the form of anger, aggression and irritability. While some of the parents used repressive disciplinary methods in dealing with the children's emotional processes, some parents chose a positive disciplinary approach. The decline in peer relationships, the change in family dynamics both economically and socially and psychologically, the social deprivation felt as a result of the isolation measures, and the increased use of technology were crucial elements of the children's socialization behavior during the pandemic. 


\section{Giriş}

Dünya Sağlık Örgütü, 30 Ocak 2020 tarihinde yeni corona virüsü (Covid-19) uluslararası öneme haiz bir halk sağlığı acil durumu ilan etmiş ve iki ay sonra Covid-19'u pandemi olarak nitelendirmiştir (World Health Organization, 2020). Pandemi küresel ölçüde sağlık açısından yarattığı risklerin yanı sıra, sosyo-ekonomik, eğitimsel ve psikolojik yönleriyle ciddi endişelere neden olmuştur (Dayal ve Tiko, 2020). Pandemi her yaştan bireyin gündelik yaşam gerçeklerini değişmiş (Jones, 2020; Lee, 2020) ve bu sürecin etkileri, gelişimsel açıdan çevresel olumsuzluklara karşı en hassas konumda olmaları nedeniyle özellikle çocukları daha savunmasız kılmıştır (Dias, Almodóvar, Atiles, Vargas ve Zúñiga León, 2020). Pandeminin başlangıcından itibaren 188 ülke 1,5 milyardan fazla çocuğu ve genci etkileyen bir tedbir alarak ülke çapında okulları kapatmıştır (Group, 2020). Birleşmiş Milletler Mayıs 2020 verilerine göre, pandemi sürecinde dünyada en az 40 milyon çocuk, erken çocukluk eğitimi ve bakım hizmetinden yoksun kalmıştır (Gromada, Richardson ve Rees, 2020).

Pandeminin hükümetler tarafından birçok ülkede yayılmasını önleyecek önlemlerin uygulanması (örneğin, okulların kapatılması ve sosyal mesafe), dünya çapında milyonlarca çocuğu ve ailelerini etkilemiştir (Organisation for Economic Co-operation and Development [OECD], 2020). Hastalığın edinim ve bulaşma riski açısından çocukların pandeminin ön saflarında yer almadığı belirtilmesine rağmen (Gudbjartsson ve diğerleri, 2020), pandeminin çocuklar üzerindeki dolaylı etkileri hafife alınmayacak derecede önemlidir. Bu süreçte çocuklar, ev ve aile yaşamları yanı sıra erken çocukluk eğitimi ve bakımı boyunca günlük rutinlerinde önemli aksamalar yaşamıştır (Barlett, Griffin ve Thomson 2020; OECD, 2020). Okullar, öğrenme merkezleri ve erken çocukluk bakım hizmeti sunan tüm kurumlar kapılarını kapatarak uzaktan öğretime geçmiştir (Kim, 2020). Bu süreçte çocuklar çeşitli erken çocukluk eğitim programlarının sağladığı sosyal etkileşim fırsatlarından mahrum kalmıştır (Long, 2020).

Çocukların sosyalleştiği ortamlar olarak okulların kapatılması, çocukların sosyal etkileşimlerini oldukça sınırlandırmış ve eğitsel yaşantılarını da çeşitli yönleriyle etkilemiştir. Erken çocukluk döneminde verilen eğitim; sosyal etkileşim, uygulamalı eğitim ve öğretim, oyun, beslenme ve günlük faaliyetler aracılığıyla sağlanmaktadır (Greszler ve Burke, 2020). Küçük çocuklar öğrenmeleri ve odaklanmaları için çok daha fazla etkileşime ve yaparak-yaşayarak öğrenme deneyimlerine ihtiyaç duymaktadır. Bu nedenle uzaktan öğrenme doğası gereği küçük çocuklar için yeterli veya uygun fırsatlar sunmamıştır (Kim, 2020).

Pandeminin sosyal izolasyon gibi kısıtlayıcı sonuçları, çocukların sosyal ve duygusal (Zhao ve diğerleri, 2020), fiziksel gelişimleri (Dunton, Do ve Wang, 2020) üzerinde önemli etkilere sahiptir. Okulların ve parkların kapatılması, etkinlik kulüpleri faaliyetlerinin durdurulması gibi alınan önlemler sonucunda çocukların akranlarıyla etkileşimlerinin azalması, çocukların psikolojik iyi oluş düzeylerini de etkilemektedir (Çiçek ve Almalı, 2020; Morgül, Kallitsoglou ve Essau, 2020). Nitekim bu dönemde yapılan araştırmalar, pandeminin çocuklarda önlenemeyen kaygı ve korkular, duygu durum bozuklukları (Şahbudak ve Emiroğlu, 2020), saldırganlık, öfkeli davranışlar (Tarkoçin, Alagöz ve Boğa, 2020) gibi psikolojik sorunlara neden olduğunu göstermiştir. Okulların kapanması ve sosyal izolasyon, çocukların teknolojik araçlarla çok daha uzun sürelerde vakit geçirmeleri ile sonuçlanarak ekrana maruz kalmayı arttırmış, bu durum çocukların sosyal ve duygusal durumlarını olumsuz etkilemiştir (Zhao ve diğerleri, 2020).

Pandemi sürecinde çocukların yaşantılarını etkileyen diğer önemli unsur ise aile yaşantısında meydana gelen değişimler ile ilgilidir. Yapılan araştırmalara göre (Chung, Lanier ve Wong, 2020; Fan 
ve diğerleri, 2020; Park, Logan, Zhang, Kamigaichi ve Kulapichitr, 2020; Samuelsson, Wagner ve $\emptyset$ degaard, 2020; Yoshikawa ve diğerleri, 2020), Covid-19 pandemisi nedeniyle erken çocukluk hizmetlerinin kapanması, ebeveynlerin çalışma biçimlerini ve çocuklarına sağladıkları bakım türlerini değiştirmiştir. Bu süreçte evden çalışan ebeveynler çocukları ile daha çok vakit geçirmiştir. Ancak birçok ebeveyn için bu sürece eşlik eden korku ve kaygılar, günlük rutinleri aynı istikrar ile sürdürmeyi zorlaştırmıştır. Küçük çocukları olan aileler; pandemiyi çocuklarına anlatmak, çocuklarını güvende tutmak, çocuklarının davranışlarını yönetmek, çocuklarının bakım ve eğitim sorumluluklarını üstlenmek, günlük rutinlerini korumak ve ev işlerini organize etmek zorunda kalmıştır (Başaran ve Aksoy, 2020). Bu süreçte ebeveynler tarafindan artan sorumluluklar, ebeveynlerin stres ve tükenmişlik düzeyini etkilemiştir (Chung ve diğerleri, 2020; Yucesoy-Özkan, Kaya, Gülboy, Altun ve Oncul, 2020). Değişen roller, rutinler ve bunlara bağlı olarak artan stres faktörleri, ebeveynlerin pandemi sürecini etkili biçimde yönetememelerine neden olabilmektedir (Brown, Doom, Watamura, Lechuga-Pena ve Koppels, 2020; Campbell 2020). Ebeveynlik davranışının, çocukların davranışları ve psiko-sosyal uyumu üzerinde önemli sonuçları olduğu (Ryan ve Deci, 2017) göz önüne alındığında, değişen aile yaşantılarının çocuklarının yaşantıları üzerinde doğrudan veya dolaylı etkilere sahip olabileceği düşünülebilir.

\section{Araştırmanın Amacı}

Pandeminin çocukların yaşantıları üzerinde çok yönlü etkileri bulunmaktadır. Bu yaşantıları erken çocukluk bağlamında ele almak, küçük yaş grubundaki çocukların afete dayanıklılı̆ını güçlendiren yolların daha iyi anlaşıımasına katkı sağlayabilir. Alanyazında pandemi sürecinin çocukların eğitim süreçlerine ve aile yaşantılarına yansımalarını ele alan çok sayıda araştırma olmasına rağmen (Barlett ve diğ., 2020; Park ve diğ., 2020; Samuelsson ve diğ., 2020), Türkiye'de ebeveyn ve öğretmen algılarına göre pandeminin erken çocukluk dönemine (0-8 yaş) yansımalarını sentezleyen bir çalışma bulunmamaktadır. Bu intiyaçtan yola çıkarak, bu araştırmada çocukları yakından gözlemleyen kişiler olan ebeveynlerin ve öğretmenlerin bakış açısından pandeminin erken çocukluk dönemine yansıyan bilgileri bütünleştirmek ve sentezlemek amaçlanmıştır. Belirtilen genel amaç doğrultusunda araştırmanın alt amaçları şu şekildedir:

Ebeveyn ve öğretmen algılarına göre Covid-19 pandemisinin erken çocukluk dönemine;

1. Bilişsel süreçler açısından yansımaları nasıl olmuştur?

2. Fiziksel durum açısından yansımaları nasıl olmuştur?

3. Duyuşsal durum açısından yansımaları nasıl olmuştur?

4. Toplumsallık açısından yansımaları nasıl olmuştur?

5. Eğitsel süreçler açısından yansımaları nasıl olmuştur?

\section{Yöntem}

\section{Araştırmanın Modeli}

Bu araştırmada, meta-sentez yöntemi kullanılmıştır. Meta-sentez, hedeflenen bir bağlam çerçevesindeki araştırmalarda ele alınan temel unsurları keşfetmek ve araştırmanın özgün sonuçlarını yeni bir kavramsallaştırma ile nihai bir ürüne çevirmek için bir grup çalışmanın bir araya getirilip analiz ve sentez süreçlerinden geçirilmesidir (Schreiber, Crooks ve Stern, 1997). Nicel araştırma sonuçlarını ortalamalara indiren meta-analiz çalışmalarının aksine meta-sentez, bireysel çalışmanın benzersizliğini yorumlayıcı bir bütüne yükselterek nitel araştırma sonuçlarını daha kapsamlı hale getirmektedir (Clemmens, 2003). France ve diğ. $(2019$, s.2), nitel araştırmaların sentezinin dört amaca 
ulaşmak için yapılabileceğini belirtir: “(1) Bir hizmetin, politikanın, stratejinin veya müdahalenin nasıl işlediğine ve insanların bunları nasıl deneyimlediğine ilişkin teori geliştirme, (2) müdahalelerin veya hizmetlerin kabul edilebilirliği, yapılabilirliği ve uygunluğuna dair kanıt sağlama, (3) kişilerin deneyimlerini aktarma, (4) karmaşık müdahalelerin geliştirilmesi, uygulanması ve değerlendirilmesi hakkında bilgilendirme." Bu çalışmada, pandemi sürecinde erken çocukluk dönemindeki çocukların deneyimlerine ilişkin bilgilerin sentezlenmesi yoluyla bir üst anlama varmak istenmiştir. Bu nedenle, meta-sentez bu araştırmanın yöntemi olarak belirlenmiştir.

Bu çalışmada, Polat ve Ay (2016, s.55)'ın önerdiği üzere, meta-sentez metodolojisinin aşamaları şu sırayla izlenmiştir: “(1) Araştırma sorularının belirlenmesi, (2) Çalışmanın konusuna uygun anahtar kelimelerin belirlenip alanyazın taramasının yapılması, (3) Kaynakların sağlanması, gözden geçirilmesi, kimliklendirilmesi ve değerlendirilmesi, (4) Araştırmanın dâhil edilme ve hariç tutulma ölçütlerinin belirlenmesi ve değerlendirmeye alınacak çalışmaların seçilmesi, (5) Seçilen çalışmaların çözümlenmesi ile ortak temalar ve bu temalara ait alt temaların oluşturulması, benzer ve farklı yönlerinin ortaya konulması, (6) Temalar çerçevesinde elde edilen bulguların sentezlenerek çıkarımların yapılması, (7) Sürecin ve bulguların ayrıntılı bir şekilde raporlaştırılması."

\section{Dâhil Etme Ölçütleri ve Tarama Süreci}

Erken çocuklukta pandeminin yansımalarına ilişkin ebeveyn ve öğretmen algılarına odaklanan, 2020-2021 yılları arasında yapılmış olan, eğitim ve eğitim araştırmaları kapsamında taranan, katılımcıları Türkiye'de olan ve nitel metodolojileri kullanan, tam metnine ulaşılan uygulamalı çalışmalar incelemeye dahil edilmiştir. Makaleler Türkçe veya İngilizce dillerinde yazılmış ve hakemli bilimsel dergilerde yayınlanmış olmalıdır. Nicel ve karma yöntem çalışmalar, teorik makaleler, incelemeler, yüksek lisans veya doktora tezleri, bildiri kitapçıkları çalışmaya dâhil edilmemiştir. Dezavantajlı çocukları (örneğin, mülteciler) ve özel gereksinimli çocukları içeren çalışmalar inceleme dışında tutulmuştur. Kültürlerarası karşılaştırma yapılan araştırmalar veri kaybı olmaması için incelemeye alınmış ancak Türk kültürü bağlamındaki bulguları analize dâhil edilmiştir.

Literatür taraması 15 Şubat 2021 ve 20 Mart 2021 tarihleri arasında gerçekleştirilmiştir. Literatür taraması, Dergipark, ERIC, Web of Science, SAGE Journals ve Scopus veritabanlarını kapsamıştır. Aramalarda kullanılan konu başlıkları ve anahtar sözcükler "erken çocukluk, çocuk, sıfırsekiz yaş, Covid-19, pandemi, ilkokul, öğrenci, ebeveyn, aile"dir. Ulusal veri tabanında "VE", "YA DA", uluslararası veri tabanlarında ise "AND", "OR" bağlaçları kavramları birleştirmek için kullanılmıştır. Literatür taramasını yürütme sorumluluğu araştırmacılar arasında paylaştırılmıştır.

\section{Tarama Sonucu}

Tarama sürecine, tekrar eden ve araştırma konusundan bağımsız yayınların makale başlıklarına göre ayrılmasıyla başlanmış, makalelerin özetleri gözden geçirilmiş ve çalışmaya dâhil edilmeyecek konu başlıkları belirlenmiştir. Mülteciler gibi dezavantajı gruplara veya özel eğitim tanısı almış çocuklara odaklanan makaleler ve uygun olmayan yöntemleri içeren makaleler incelemeye alınmamıştır. Literatür taraması sonuçları, meta-sentez işlemlerini rapor etmek için Moher, Liberati, Tetzlaff ve Altman (2009) tarafından önerilen akış diyagramında (PRISMA) ayrıntılı olarak açıklanmıştır (Şekil 1). Tarama sonucunda çalışmaya uygun olduğu belirlenen tam metin 17 makale tamamen okunmuştur. Bu araştırmalar dâhil etme ve hariç tutma ölçütlerine göre tekrar gözden geçirilmiştir. 1 makale tekrar etmesi nedeniyle, 1 makale ise yetersiz veri sunması nedeniyle çıkarılmıştır. Araştırmacılar tarama sürecine başlarken bağımsız çalışmışlar, daha sonra bir araya gelerek uygun olan makaleler üzerine fikir birliğine varmışlardır. Meta-senteze dâhil edilecek nitelikte 
çalışmalar; çalışmanın amacı, yöntemi, dâhil etme ölçütleri ve çalışma değeri göz önünde tutularak karar verilmiştir.

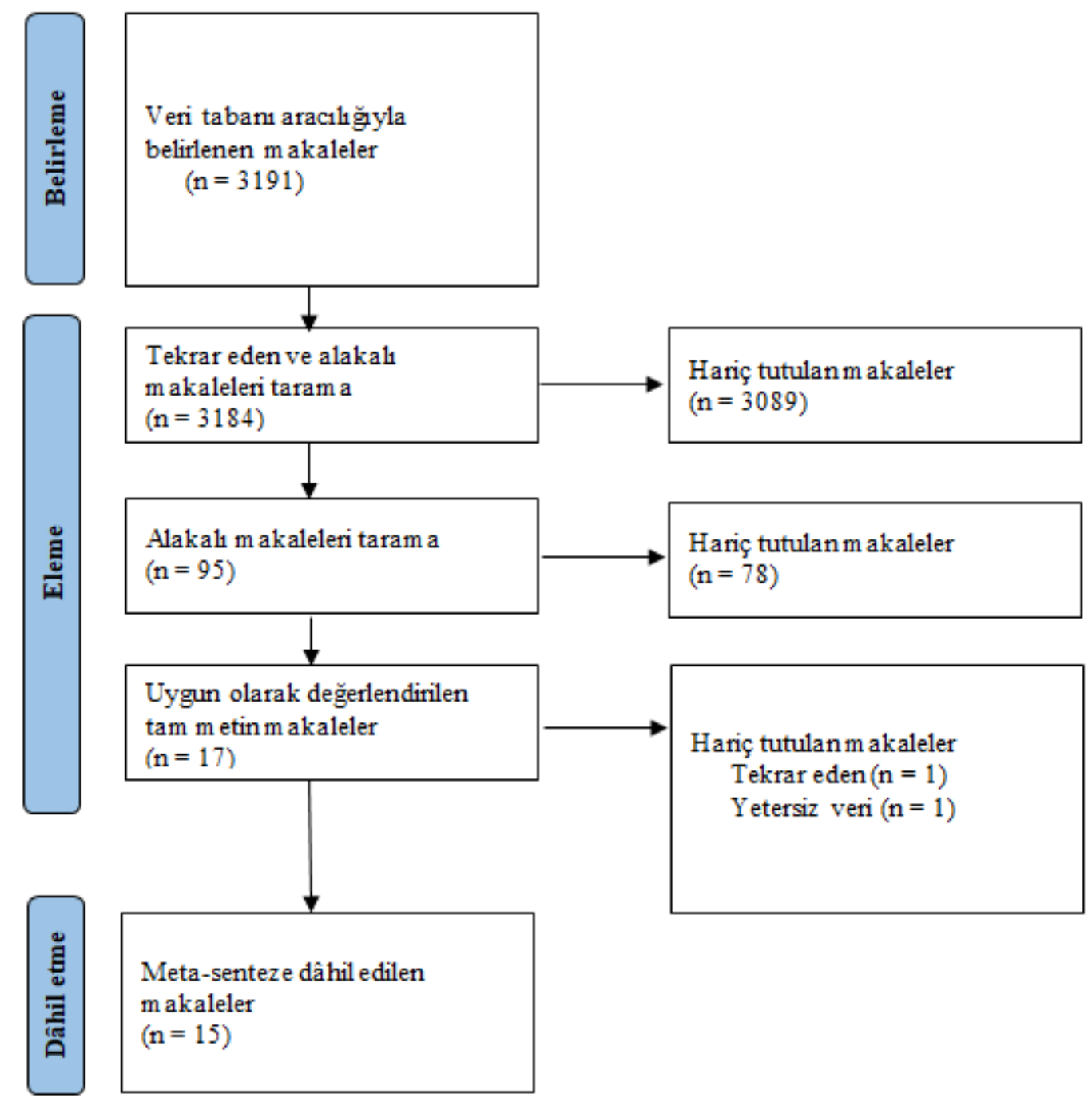

Şekil 1. PRISMA akış diyagramı

\section{Veri Çıkarma ve Sentezleme}

Bu aşamada analiz sürecine dâhil edilen makaleler tekrarlayıcı biçimde okunmuştur. Analiz sürecine dâhil edilen makalelerin özellikleri Tablo 1'de sunulmuştur. Takip eden aşamada araştırmacılar bağımsız olarak seçilen çalışmaları çözümleyerek kodları, kategorileri ve alt kategorileri belirlemişlerdir. Daha sonra, belirlenen kategori ve alt kategoriler üzerinde anlaşmışlardır. Bulguların sentezi yoluyla elde edilen çıkarımlar, alan yazın ile beraber ele alınmışıı. 
Tablo 1.

Incelemeye dâhil edilen çalışmaların özellikleri

\begin{tabular}{|c|c|c|c|c|c|c|}
\hline Kod & Yazar/Yıl & $\begin{array}{l}\text { Veri } \\
\text { Tabanı }\end{array}$ & Amaci & Katılımeı & Yöntem & $\begin{array}{l}\text { Veri Toplama } \\
\text { Yöntemi/Veri } \\
\text { Analizi }\end{array}$ \\
\hline M1 & $\begin{array}{l}\text { Kurt- } \\
\text { Demirbaş ve } \\
\text { Sevgili- } \\
\text { Koçak } \\
(2020)\end{array}$ & Dergipark & $\begin{array}{l}\text { 2-6 yaş arasında } \\
\text { çocuğu olan } \\
\text { ebeveynlerin } \\
\text { salgın sürecine } \\
\text { bakış açılarının, } \\
\text { duygularının ve } \\
\text { yaşamlarında } \\
\text { meydana gelen } \\
\text { değişimlerin } \\
\text { incelenmesi ve } \\
\text { çocuklarda bu } \\
\text { süreçte } \\
\text { yaşanılan } \\
\text { değişimlerin } \\
\text { belirlenmesi }\end{array}$ & $\begin{array}{l}\text { 2-6 yaş } \\
\text { arasinda } \\
\text { çocuğu olan } \\
\text { ebeveyn } \\
(n=30)\end{array}$ & Fenomenoloji & $\begin{array}{l}\text { Yarı } \\
\text { yapılandırılmış } \\
\text { görüşme formu }\end{array}$ \\
\hline M2 & $\begin{array}{l}\text { Demir- } \\
\text { Öztürk, Kuru } \\
\text { ve Demir- } \\
\text { Y1ldız } \\
(2020)\end{array}$ & Dergipark & $\begin{array}{l}\text { Okul öncesi } \\
\text { dönemdeki } \\
\text { çocuklar ve } \\
\text { annelerinin } \\
\text { pandemi ve yeni } \\
\text { koronavirüs } \\
\text { hakkındaki } \\
\text { algılarının } \\
\text { belirlenmesi }\end{array}$ & $\begin{array}{l}5 \text { yaş çocuk } \\
(n=14), \\
5 \text { yaş çocuk } \\
\text { annesi } \\
(n=14)\end{array}$ & $\begin{array}{l}\text { Durum } \\
\text { çalışması }\end{array}$ & $\begin{array}{l}\text { Yarı } \\
\text { yapplandırılmış } \\
\text { görüşme formu }\end{array}$ \\
\hline M3 & $\begin{array}{l}\text { Akkaş- } \\
\text { Baysal, Ocak } \\
\text { ve Ocak } \\
(2020)\end{array}$ & Dergipark & $\begin{array}{l}\text { EBA } \\
\text { uygulaması ve } \\
\text { diğger uzaktan } \\
\text { eğitim } \\
\text { faaliyetlerine } \\
\text { ilişkin okul } \\
\text { öncesi velilerin } \\
\text { görüşlerinin } \\
\text { ortaya } \\
\text { çkarılması }\end{array}$ & $\begin{array}{l}\text { Okul öncesi } \\
\text { kurumuna } \\
\text { kayitlı } \\
\text { çocuğu olan } \\
\text { ebeveyn } \\
(n=20)\end{array}$ & Fenomenoloji & $\begin{array}{l}\text { Yarı } \\
\text { yapplandırılmış } \\
\text { görüşme formu }\end{array}$ \\
\hline M4 & $\begin{array}{l}\text { Yüksek-Usta } \\
\text { ve Gökcan } \\
(2020)\end{array}$ & Dergipark & $\begin{array}{l}\text { Okul öncesi } \\
\text { çocukların ve } \\
\text { annelerinin } \\
\text { Covid-19 } \\
\text { salgınına } \\
\text { yönelik } \\
\text { görüşlerinin } \\
\text { incelenmesi }\end{array}$ & $\begin{array}{l}6 \text { yaş çocuk } \\
(n=11), \\
6 \text { yaş çocuk } \\
\text { annesi } \\
(n=11)\end{array}$ & $\begin{array}{l}\text { Temel nitel } \\
\text { araştırma }\end{array}$ & $\begin{array}{l}\text { Yarı } \\
\text { yapılandırılmış } \\
\text { görüşme formu } \\
\text { Çocuk resimleri } \\
\text { Doküman analizi }\end{array}$ \\
\hline M5 & $\begin{array}{l}\text { Karabudak } \\
(2020)\end{array}$ & Dergipark & $\begin{array}{l}\text { İlkokul } 1 . \text { sınıf } \\
\text { öğretmenlerinin } \\
\text { Covid-19 salgın } \\
\text { sürecinde }\end{array}$ & $\begin{array}{l}6 \text { yaş } \\
\text { grubuna } \\
\text { eğitim veren } \\
\text { sınıf }\end{array}$ & Fenomenoloji & $\begin{array}{l}\text { Yarı } \\
\text { yapılandırılmış } \\
\text { görüşme formu }\end{array}$ \\
\hline
\end{tabular}




\begin{tabular}{|c|c|c|c|c|c|c|}
\hline & & & $\begin{array}{l}\text { uzaktan eğitime } \\
\text { uyum } \\
\text { süreçlerine } \\
\text { ilişkin } \\
\text { deneyimlerinin } \\
\text { incelenmesi }\end{array}$ & $\begin{array}{l}\text { öğretmeni } \\
(n=9)\end{array}$ & & İçerik analizi \\
\hline M6 & $\begin{array}{l}\text { Alisinanoğlu, } \\
\text { Karabulut ve } \\
\text { Türksoy } \\
(2020)\end{array}$ & Dergipark & $\begin{array}{l}\text { Pandemi } \\
\text { sürecinde sosyal } \\
\text { izolasyona } \\
\text { maruz bırakılan } \\
\text { okul öncesi } \\
\text { çocukların } \\
\text { yaşadıkları } \\
\text { korkuların } \\
\text { belirlenmesi ve } \\
\text { bu bağlamda } \\
\text { ailelerin nasıl } \\
\text { çözüm yolları } \\
\text { ürettiklerinin } \\
\text { tespit edilmesi }\end{array}$ & $\begin{array}{l}\text { 0-6 yaş } \\
\text { çocuğu olan } \\
\text { ebeveyn } \\
(n=34)\end{array}$ & $\begin{array}{l}\text { Temel nitel } \\
\text { araştırma }\end{array}$ & $\begin{array}{l}\text { Yapılandırılmış } \\
\text { görüşme formu } \\
\text { İçerik analizi }\end{array}$ \\
\hline M7 & $\begin{array}{l}\text { Aytaç } \\
(2021)\end{array}$ & ERIC & $\begin{array}{l}\text { Covid-19 salgını } \\
\text { sırasında eğitim } \\
\text { sürecinde } \\
\text { öğretmenlerin } \\
\text { karşılaştığı } \\
\text { sorunların } \\
\text { ortaya } \\
\text { çıkarılması }\end{array}$ & $\begin{array}{l}\text { Okulöncesi, } \\
\text { ilkokul, } \\
\text { ortaokul ve } \\
\text { özel eğitim } \\
\text { öğretmeni } \\
(n=80)\end{array}$ & Fenomenoloji & $\begin{array}{l}\text { Yarı } \\
\text { Yapılandırılmış } \\
\text { görüşme formu } \\
\text { İçerik analizi }\end{array}$ \\
\hline M8 & $\begin{array}{l}\text { Cakin ve } \\
\text { Kulekci- } \\
\text { Akyavuz } \\
(2021)\end{array}$ & ERIC & $\begin{array}{l}\text { Covid-19 salgını } \\
\text { sırasında } \\
\text { uzaktan eğitim } \\
\text { sürecinin } \\
\text { ebeveynlerin } \\
\text { bakış açısından } \\
\text { incelenmesi }\end{array}$ & $\begin{array}{l}\text { ilkokul } \\
\text { çağında } \\
\text { çocuğu olan } \\
\text { ebeveyn } \\
(n=20)\end{array}$ & Fenomenoloji & $\begin{array}{l}\text { Yarı } \\
\text { yapılandırılmış } \\
\text { görüşme formu } \\
\text { İçerik analizi }\end{array}$ \\
\hline M9 & $\begin{array}{l}\text { Inan } \\
(2021)\end{array}$ & ERIC & $\begin{array}{l}\text { Reggio } \\
\text { Emilia'dan ilham } \\
\text { alan } \\
\text { Türkiye'deki } \\
\text { erken çocukluk } \\
\text { eğitimcilerinin } \\
\text { Yeni Normal'de } \\
\text { yaşadıkları i ilişkin } \\
\text { zorluklara } \\
\text { algılarının ve } \\
\text { deneyimlerinin } \\
\text { incelenmesi }\end{array}$ & $\begin{array}{l}\text { Erken } \\
\text { çocukluk } \\
\text { eğitimcisi } \\
(n=226)\end{array}$ & 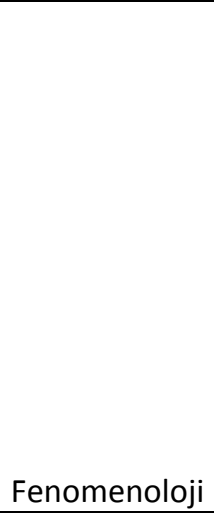 & $\begin{array}{l}\text { Yarılandırılmamış } \\
\text { görüşme formu } \\
\text { İçerik analizi ve } \\
\text { tematik analiz }\end{array}$ \\
\hline M10 & $\begin{array}{l}\text { Toran vd. } \\
(2021)\end{array}$ & $\begin{array}{l}\text { SAGE } \\
\text { Journals }\end{array}$ & $\begin{array}{l}\text { Türk ve Çinli } \\
\text { ebeveynlerin } \\
\text { Covid-19 } \\
\text { karantina } \\
\text { sürecinde } 3-6 \\
\text { yaşlarındaki } \\
\text { çocuklarıyla } \\
\text { yaşadıkları }\end{array}$ & $\begin{array}{l}\text { 3-6 yaş } \\
\text { çocuğu olan } \\
\text { Türk } \\
(n=13) \text { ve } \\
\text { Çinli } \\
\text { ebeveyn } \\
(n=11)\end{array}$ & $\begin{array}{l}\text { Temel nitel } \\
\text { araştırma }\end{array}$ & $\begin{array}{l}\text { Yarı } \\
\text { yapılandırılmış } \\
\text { görüşme formu } \\
\text { Tümevarımsal ve } \\
\text { tümdengelimsel } \\
\text { analiz }\end{array}$ \\
\hline
\end{tabular}




\begin{tabular}{|c|c|c|c|c|c|c|}
\hline & & & $\begin{array}{l}\text { deneyimlerin } \\
\text { incelenmesi }\end{array}$ & & & \\
\hline M11 & $\begin{array}{l}\text { Fidan } \\
(2020)\end{array}$ & Dergipark & $\begin{array}{l}\text { Covid-19 salgını } \\
\text { sonucu } \\
\text { gerçekleşen } \\
\text { zorunlu uzaktan } \\
\text { eğitime ilişkin } \\
\text { öğretmen } \\
\text { görüşlerinin } \\
\text { incelenmesi }\end{array}$ & $\begin{array}{l}\text { Sınıf } \\
\text { öğretmeni } \\
(n=23)\end{array}$ & Fenomenoloji & $\begin{array}{l}\text { Yarı } \\
\text { yapılandırılmış } \\
\text { görüşme formu } \\
\text { İçerik analizi }\end{array}$ \\
\hline M12 & $\begin{array}{l}\text { Erol ve Erol } \\
\text { (2020) }\end{array}$ & Dergipark & $\begin{array}{l}\text { Yeni tip } \\
\text { koronavirüs } \\
\text { pandemisi } \\
\text { sürecinde ilkokul } \\
\text { öğrencilerinin } \\
\text { deneyimlerinin } \\
\text { ebeveynlerinin } \\
\text { gözünden } \\
\text { incelenmesi }\end{array}$ & $\begin{array}{l}\text { İlkokul } \\
\text { çocuğu olan } \\
\text { ebeveyn } \\
(n=11)\end{array}$ & Fenomenoloji & $\begin{array}{l}\text { Yarı } \\
\text { yapılandırılmış } \\
\text { görüşme formu } \\
\text { İçerik analizi }\end{array}$ \\
\hline M13 & $\begin{array}{l}\text { Demir ve } \\
\text { Özdaş } \\
(2020)\end{array}$ & Dergipark & $\begin{array}{l}\text { Covid } 19 \\
\text { sürecinde } \\
\text { ilkokuldaki } \\
\text { uzaktan eğitim } \\
\text { faaliyetlerine } \\
\text { ilişkin öğretmen } \\
\text { görüşlerinin } \\
\text { incelenmesi }\end{array}$ & $\begin{array}{l}\text { Sınıf } \\
\text { öğretmeni } \\
(n=44)\end{array}$ & $\begin{array}{l}\text { Durum } \\
\text { çalışması }\end{array}$ & $\begin{array}{l}\text { Yapılandırmamış } \\
\text { görüşme formu } \\
\text { İçerik analizi }\end{array}$ \\
\hline M14 & $\begin{array}{l}\text { Yurtbakan ve } \\
\text { Akyıldız } \\
(2020)\end{array}$ & Dergipark & $\begin{array}{l}\text { Covid-19 } \\
\text { izolasyonu } \\
\text { döneminde } \\
\text { gerçekleştirilen } \\
\text { uzaktan eğitim } \\
\text { faaliyetleri } \\
\text { hakkında ilkokul } \\
\text { öğretmenlerinin, } \\
\text { ilkokul } \\
\text { öğrencilerinin ve } \\
\text { velilerinin } \\
\text { görüşlerinin } \\
\text { incelenmesi }\end{array}$ & $\begin{array}{l}\text { Ebeveyn } \\
(n=13) \\
\text { İlkokul } \\
\text { öğrencisi } \\
(n=13) \\
\text { Sınıf } \\
\text { öğretmeni } \\
(n=13)\end{array}$ & Fenomenoloji & $\begin{array}{l}\text { Yarı } \\
\text { yapılandırılmış } \\
\text { görüşme formu } \\
\text { Betimsel analiz }\end{array}$ \\
\hline M15 & $\begin{array}{l}\text { Balaman ve } \\
\text { Hanbay- } \\
\text { Tiryaki } \\
(2021)\end{array}$ & Dergipark & $\begin{array}{l}\text { Covid-19 } \\
\text { sürecinde } \\
\text { mecburi olarak } \\
\text { yürütülen } \\
\text { uzaktan eğitim } \\
\text { hakkında } \\
\text { öğretmen } \\
\text { görüşlerinin } \\
\text { araştırılması }\end{array}$ & $\begin{array}{l}\text { Sınıf } \\
\text { öğretmeni } \\
(n=10)\end{array}$ & Fenomenoloji & $\begin{array}{l}\text { Yarı } \\
\text { yapılandırılmış } \\
\text { görüşme formu } \\
\text { İçerik analizi }\end{array}$ \\
\hline
\end{tabular}




\section{Bulgular ve Tartışma}

$\mathrm{Bu}$ araştırmaya ebeveynlerin ve öğretmenlerin bakış açısından pandeminin erken çocukluk dönemine yansımalarını konu edinen çalışmalar dâhil edilmiştir. Durum çalışması ve temel nitel araştırma ile desenlenmiş çalışmalar dışında, fenomenoloji ile desenlenen çalışmaların katılımcı sayıları ortalama 10-20 arasında değişmiştir. Araştırmalarda $(n=12)$ genellikle veri toplama aracı olarak yarı yapılandırılmış görüşme formu kullanılmış ve bu çalışmalarda veriler daha çok içerik analizi yoluyla analiz edilmiştir İncelenen çalışmalarda, ailelerin gündelik yaşamlarında, çocukların sosyal ve eğitimsel yaşantılarında pandemiyi nasıl deneyimledikleri tanımlanmıştır. Bu çalışmalar, pandeminin insan yaşamını bir 'yapboz' etkisiyle nasıl değiştirdiğini ve çocukların dünyasına nasıl bir gerçeklik inşa ettiğini anlatmıştır.

Bu araştırmada bulgular, erken çocukluk dönemi bağlamında konumlandırmaya çalışılımıştır. Incelenen çalışmalarda olduğu gibi bu çalışmada da çocukların yaşantılarına temel olan unsurlar okul ve ev ortamına eklenen sanal dünya fenomeni ile iç içe yer almıştır. Bu kapsamda çalışmada "bilişsel süreçler", "fiziksel durum", "duyuşsal durum", "toplumsallık" ve "eğitsel süreçler" olmak üzere beş ana kategori ortaya çıkmıştır. Bu ana kategorilerin altında 15 alt kategori yer almıştır. Çalışmada ortaya çıkan ana kategoriler ve alt kategoriler Tablo 2'de gösterilmiştir.

Tablo 2.

Covid-19 pandemisinin erken çocukluk dönemine yansımalarına ilişkin kategoriler ve alt kategoriler

\begin{tabular}{ll}
\hline Kategori & Alt Kategori \\
\hline Bilişsel Süreçler & Pandemiyi anlamlandırma \\
Fiziksel Durum & Sağıklı beslenme ve temizlik \\
& Spor ve hareket \\
& Fiziksel görünümde değişim \\
Duyuşsal Durum & Duygusal iyi oluş \\
& Duyguların ifade edilişi \\
& Duyguların yönetimi \\
Toplumsallık & Akran ilişkileri \\
& Aile içi dinamikler \\
& Sosyal mahrumiyet \\
& Teknoloji kullanımı \\
& Öğrenme paydaşları \\
Eğitsel Süreçler & Öğrenme \\
& Duyuşsal yaklaşım \\
& Engeller \\
\hline
\end{tabular}

\section{Bilişsel Süreçler}

Bu çalışmada, çocukların pandeminin tanımına, belirtilerine ve nasıl önlem alınacağına yönelik sorular sorarak anlamlandırdıkları ortaya çıkmıştır (M1, M2, M4, M6, M7). Çocuklar, pandemiye ilişkin kavramları virüs, bulaşıcı, zararlı olarak kavramsallaştırmış ve pandeminin sağlıkla ilgili önemli düzeyde tehdit içerdiğini bildirmiştir. Ancak çok küçük yaştaki bazı çocuklar bu sürecin farkında olmamıştır. Bu durum, Piaget'in (1972) bilişsel gelişim kuramına göre, 2-6 yaş arası çocukların işlem öncesi dönemde olmalarıyla açıklanabilir. İşlem öncesi dönemde çocuklar, parça ve bütün ilişkisini kuramazlar (Kol, 2011), dolayısıyla çok küçük yaştaki çocuklar pandemi olgusunu kavramayabilirler. 
Çocukların pandemiyi öğrenme kaynakları sırasıyla aile, medya, öğretmen olarak ortaya çıkmıştır. Bazı aileler çocuklarına pandemiyi açıklayıcı, bazıları öyküleyici biçimde, bazıları ise somutlaştırarak anlatmaya çalışmıştır (M1, M4). Bazı ailelerin pandemiyi çocuklara anlatırken; pandemiyi anlatmama, çarpıtma veya yanlış bilgi verme, dini kavramlarla geçiştirme, çocuğu görmezden gelme gibi yaklaşımlar izledikleri ortaya çıkmıştır (M6, M1). Bu noktada, çocukların pandemiyi eksik veya yanlış kavramsallaştırabildikleri gözlenmiştir. Vygotskian bakış açısına göre, kişinin yaşadığı sosyal çevre ve kültür, olguları ve kavramları anlamlandırmasına temel oluşturmaktadır. Çocuğun bilişsel gelişimini sağlayan araçlar olarak kültür, dil ve çevresel kaynakların bilişsel gelişimlerine kaynaklık etmesi (Miller, 1994) nedeniyle ailelerin davranışları ve yeterlikleri bilişsel gelişim üzerinde oldukça etkilidir. Bu nedenle ebeveynlerin pandemiyi çocuklara etkili yollarla açıklamaları, çocukların pandemi sürecini doğru kavramsal bağlar kurarak anlamlandırmalarına ve özümsemelerine katkıda bulunabilir. Bu çalışmada ortaya çıkan ailelerin çocuklara pandemiyi açıklamama, çarpıtma ve metafizik yollarla açıklama yaklaşımları ise, küçük yaş grubu çocuklar tarafından pandeminin doğru kavramsallaştırmasını engelleyebilir.

\section{Fiziksel Durum}

Eve kapanmanın çocuklar üzerindeki en belirgin etkilerinden biri fiziksel durumla ilgili olarak ortaya çıkmıştır (M1, M2, M4, M7, M10, M12). Bazı çocuklarda pandemi kaynaklı sağıı sorunlarının ortaya çıktığı gözlenmiştir. Eve kapanmayla birlikte fiziksel hareketin oldukça azalması ve artan ekran süresi, çocuklarda kilo artışı beraberinde fiziksel görünümünün değişmesine neden olmuştur (M1, M7, M10, M11). Fiziksel etkinlikler, çocukların fiziksel ve psikolojik gelişimi için temel dayanaklarından birisini oluşturarak psikolojik sağlığın iyileştirilmesi için temel bir araç olarak kabul edilir (Dunton ve diğ., 2020). Bu nedenle, fiziksel etkinliklerin az olması ve ekrana fazla maruz kalma nedeniyle artan hareketsizlik, psikososyal iyi olma hali dâhil olmak üzere sağlıkla ilgili birçok sorunu tetikleyebilir (Hinkley, Brown, Carson ve Teychenne 2018).

Fiziksel durumla ilişkili ikincil bulgu, pandemi sürecinde sağlıklı beslenme, temizlik gibi alışkanlıkların ve tedbirlerin ön plana çıkmasıdır. Bu dönemde genel olarak temel ihtiyaçlara verilen önem artmış, beslenme alışkanlığında değişimler meydana gelmiştir. Bazı aileler günlük rutinlerinin değişmesinden olumsuz etkilenmiş ve düzensiz uyku, esnek yemek yeme alışkanlıkları ortaya çıkmıştır. Bazı aileler ise günlük rutinlerini koruduklarını, pandemi sürecinde yemek ve uyku saati gibi düzenlerinin değişmediğini bildirmiştir. Weisner (2010)'e göre, kişilerin aile üyeleriyle beraber kaynakları, değerleri ve amaçları ile uyumlu biçimde günlük rutinlerini sürdürmeleri, bireylerin iyi oluş durumlarına benzersiz biçimde yanıt vermektedir. Bu noktada, kişilerin yaşantılarında öngörülemezlik ve belirsizliğe neden olan salgın sürecinde gündelik rutinleri mümkün ölçüde sürdürmek, bireylerin iyi oluşları için oldukça önemlidir. İspanya'da 0-12 yaş aralığında 837 çocuğun pandemi sürecinde fiziksel etkinliklerini ve rutinlerini ortaya koyan bir çalışmada (Cachón-Zagalaz, Zagalaz-Sánchez, ArufeGiráldez, Sanmiguel-Rodríguez ve González-Valero, 2021) benzer biçimde, dijital ekranların kullanımı, çocukların günlük rutininin önemli bir parçası olarak ortaya çıkmıştır. Bu nedenle çocukların fiziksel etkinlik seviyeleri oldukça düşük düzeyde kalmıştır. Bu sonuçlar, ev ortamında fiziksel etkinlik ve hareketin artırılması için önlemler alınması gerektiğine işaret etmektedir. İncelenen çalışmalarda çok az sayıda aile, açık havada çocuklarıyla daha uzun vakit geçirdiğini ve evde spor yapma alışkanlığını geliştirdiğini bildirmiştir. Buna paralel olarak, ailelerin çocuklarıyla fiziksel hareketler ve egzersizler yaptıklarını gösteren bulgular oldukça sınırıdır.

Özellikle erken çocukluk döneminde gelişim açısından çok önemli rolü olan çocuk oyunları fiziksel hareketi arttırmak için fırsat tanıyabilir. Okul ortamında genellikle oyun araçları ve kuralları gibi her adımı tasarlamış oyunlar oynanırken, ev ortamı gibi bağlamlar aslında, gelişimi bütüncül yönleriyle destekleyecek yapılandırımamış oyunlara fırsat tanımaktadır. Özellikle küçük yaş çocuklar 
(5-8 yaş) daha büyük çocuklara (9-13 yaş) göre yapılandırılmamış oyunlara karşı daha çok meyillidirler (Eyler, Nanney, Brownson, Lohman ve Haire-Joshu, 2006). Incelenen çalışmalarda, evde yapılandırılmamış oyunların oynandığına ilişkin çok sınırlı bir bulgu ile karşılaşılmışır. Çocukların ev ortamında televizyon seyrederek ekran karşısında uzun sürelerde hareketsiz kalmaları, çocukların fiziksel gelişimleri üzerinde ciddi sıkıntılar oluşturmaktadır (Dunton ve diğerleri, 2020). Pandemi sürecinde evde kalmanın daha çok hareketsizliğe neden olduğu ve oyun etkinliklerinin sınırlı olduğu yönündeki bulgular, aileler tarafından yapılandırılmamış oyun için ev ortamının etkili biçimde değerlendirilmediğini düşündürmektedir.

\section{Duyuşsal Durum}

Pandemi sürecinin çocukların duyuşsal durumlarına olan yansımalarına ilişkin bulgular; duygusal iyi oluş, duyguların ifade edilişi, duyguların yönetimi altında gruplanmıştır. Duygusal iyi oluş üzerine bulgular incelendiğinde çocukların stres, endişe, kaygı, korku, merak, kıskançlık, şaşkınlık, hayal kırıklığı, pişmanlık, yalnızlık, telaş, vicdani rahatsızlık, mutsuzluk, çekimserlik, tedirginlik, sıkılma, yorgunluk, özlem gibi duygular geliştirdikleri ve bu duyguların süreç içinde değişkenlik gösterdiği ortaya çıkmıştır. Bulgularda, çocukların hareket özgürlüğünün kısıtlanmasının yarattığı gerginlik ve belirsizlik duygularının sıklıkla vurgulandığı görülmüştür (M1, M2, M4, M8, M10, M12). Bununla birlikte bazı çalışmalarda aile ile nitelikli zaman geçirme fırsatına bağlı olarak evde kalmaya ilişkin hoşnut olma, saygı, özgüven, cesaret, mutluluk, umutlu olma, heyecan, huzur, minnettarlık, empati gibi duygu durumlarının olduğu da belirtilmiştir (M1, M4, M11). Bazı çalışmalarda ise herhangi bir duygusal değişimin olmadığı veya duygusal süreçlere ilişkin kararsızlık yaşandığı ifade edilmiştir (M1, M4).

Duygusal iyi oluş, bireyin yaşamındaki olumlu duyguların varlığı ya da yokluğunu yansıtan belirtiler bütünüdür. Bireyin olumlu ruh halinde olması pozitif etkilerin varlığı olarak ele alınırken, bireyin umutlu bir ruh hali içinde olması ise negatif etkilerin yokluğu olarak değerlendirilir (Keyes, 2002). Ecclestone (2012)'a göre duygusal iyi oluş; iyimserlik, esneklik, sabır, desteklenme, anlık olarak yeteneklerini kullanma, sevilme, duygu düzenleme becerileri, saygı duyulma, empati, sakinlik, merhamet duyguları ile ilişkilidir. Bulgular, çocuklarında olumlu duyguları gözlemleyen aile bireylerinin çocuklarıyla daha etkili vakit geçirdiklerini ifade ettiğini ortaya koyması yönüyle oldukça kritiktir. Bu yöndeki bulgular, pandemi sürecinde çocuklarda duygusal iyi oluşun çocukların sosyal ve duygusal ihtiyaçlarının karşılanması ile ilgili olabileceğine işaret etmektedir.

Duyguların çocuklar tarafından ifade ediliş biçimleri değerlendirildiğinde, çocukların hırçınlık gösterme, tedbir ve kurallara aşırı bağııık (M4); bağırma, nedensiz ağlama, öfke nöbetleri (M6); saldırganlık ve asi davranışlar sergiledikleri (M10, M12) belirtilmiştir. Çocuklar deneyimledikleri fakat ifade edemedikleri duyguları ağlama, öfke nöbetleri, saldırganlık gibi yollarla dışavurabilirler (Çağdaş ve Şahin-Seçer, 2015). Bazı ailelerde çocukların üzüntü, öfke, korku, kıskançlık gibi duyguları ifade etmesi, güçsüzlüğün yansıması ya da ayıp olarak değerlendirilerek yetişkinler tarafından hoş karşılanmamaktadır (Ersan, 2017). Afetler gibi yıkıcı etkisi olan olaylar sonrasında, çocukların duygusal durumları etkilenmekte ve bu duygular çocukların davranışlarına çok çeşitli yollarla yansıyabilmektedir. Bu bağlamda önem arz eden durum, olumsuz duyguların sıklığı, yoğunluğu ve ifadesidir (Ersan, 2017). Bu bakımdan çocuklarda salgın süreçlerinin olumsuz psikolojik etkilerini önleyen destek mekanizmalarının geliştirilmesi oldukça önemlidir.

Çocukların duygu durumlarının ve duygularını ifade ediş biçimlerinin aileler tarafından nasıl yönetildiğine dair bulgular incelendiğinde; bazı ebeveynlerin çocuğa bağırma, fiziksel ceza uygulama veya çocuğu yalnız bırakma gibi disiplin stratejileri tercih ettikleri (M10) belirtilmiştir. Öte yandan, bazı ebeveynler ise çocuklarıyla konuşma, onları bilgilendirme, oyun oynama, telkin ve sohbet gibi 
yöntemleri kullanarak çocuklarına duygusal destek vermiştir (M6). Çocukların duygusal durumlarına karşı gösterilen davranışlar, ailelerin sosyal ve kültürel bağlamına göre de değişkenlik göstermiştir. Aileler bağlamında değişen bu bulgular, otoriter veya demokratik ebeveyn tutum ve yaklaşımları ile ilgili olabilecektir. Çocuklara otoriter ebeveyn tutumlarıyla yaklaşmak, çocukların suçluluk hissederek daha çok içine kapanmalarına veya daha saldırgan davranışlar göstermelerine neden olabilir (Saylık ve Yalçın, 2018). Bu nedenle, pandemi sürecinin yönetiminde çocuklar ile duygusal bağlar kurmak çocukların duygusal öz düzenlemelerine katkıda bulunarak istenmeyen davranışları önlemede daha etkili sonuçlar verebilir.

\section{Toplumsallık}

Pandeminin çocukların toplumsallıklarına yönelik yansımalarına bakıldığında araştırma bulgularının; akran ilişkileri, aile içi dinamikler, sosyal mahrumiyet ve teknoloji bağımlılı̆ı eksenlerinde yoğunlaştığı görülmüştür. Akran ilişkilerine yönelik yansımalara ilişkin bulgular; akranlara duyulan özlem, yalnız kalmaktan korkma ve hayali arkadaşlıklar üretme (M1, M2, M12, M7, M10, M6) bulgularını ortaya koymuştur. Bulgular, çocukların akranlarıyla sosyal bağları yeniden kurma ihtiyacına işaret etmiştir. Bu noktada, ailelerin çocukları ile etkili vakit geçirerek çocuklarına gerekli duygusal desteği sağlayabilmeleri oldukça değerlidir ve kısıtlayıcı önlemlerin olumsuz sonuçlarını sınırlamak için anahtar olabilir (Usher, Bhullar ve Jackson, 2020).

Bulgular aile içi dinamikler temelinde değerlendirildiğinde; ebeveynlerin çocuklarıyla daha fazla kaliteli zaman geçirme fırsatı elde ettikleri, öncesinde çocuklarına yeterince özen göstermediklerini fark ettikleri, daha çok fiziksel ve psikolojik yakınlık geliştirdikleri ve etkileşim kurabildikleri, çocuklarını daha yakından tanıma fırsatı buldukları ve aile ilişkilerinde iyileşme olduğu ifade edilmiştir. Ayrıca, aile yaşantılarında günlük rutinlerin ve uyku düzeninin değiştiği, uzun süre evde kalmaktan kaynaklı duygu değişimlerinin yaşandığı belirtilmiştir. Gündelik alışkanlıkların değişmesi, telefon ve sosyal medya kullanım sıklığında artış, aile içi dinamikler üzerinde belirleyici olmuştur. Aile içi değişen dinamikler sonucunda beliren aile içi sorunlar nedeniyle çocukların daha fazla endişeli oldukları ve asi davranışlar sergiledikleri vurgulanmıştır (M1, M2, M4, M6, M10).

Bulgular, sosyal mahrumiyet açısından ele alındığında, çocukların hareket özgürlüklerinin ve sosyal yaşamlarının kısıtlandığı, sevdiklerine özlem duydukları, yalnızlık hissettikleri, okulu unutacaklarına ilişkin endişe geliştirdikleri, ev dışında hastalık nedeniyle özgürce hareket edememekten kaynaklı kaygı duydukları, okula gidememenin üzüntüsünü yaşadıkları, akranlarından uzak kalmaları neticesinde sosyal çevrenin azalması ile saldırgan davranışların arttığı gözlenmiştir (M1, M2, M4, M10, M12). Bu sonuçlar, sosyal mahrumiyetin çocukların duygusal durumlarını doğrudan etkilediğini göstermektedir. Pandeminin sebep olduğu zorunlu izolasyon hem çocukların hem de yetişkinlerin sosyal ilişkilerini azaltmış ve yalnızlık hislerini artırmıştır. Toplumsal yaşamdaki sosyal ilişkilerin her yaşta birey için ruh sağıı̆ını koruyucu bir unsur olduğu dikkate alınırsa, pandeminin çocuklar ve ebeveynlerin ruhsal durumuna olumsuz etkide bulunması beklenen bir durumdur (Bozkurt, Zeybek ve Aşkın, 2020). Ancak ele alınan araştırmalara göre, izole edilmişlik, yalnızlık, arkadaş özlemi gibi toplumsalığa yönelik duyguların her çocukta gözlenmediği de ortaya çıkmıştır. Ebeveynlerin çocuklara bu süreçte verdikleri bilginin ve ilginin niteliği, dönütlerin içeriği, evde kardeşlerin varlığı ve sosyal destek unsurları bu farklılaşmaya kaynaklık edebilir.

Pandeminin toplumsallık bağlamında erken çocukluk dönemine en önemli etkileri teknoloji kullanımı dolayısıyla ortaya çıkmışır. İncelenen çalışmalarda, küçük yaştaki çocukların telefon, tablet, TV gibi teknolojik araçları kullanımında artış olduğu sıklıkla belirtilmiştir (M1, M4, M5, M8, M11, M12). Pandemi sürecinde çocukların ev ortamında geçirdikleri dijital zaman artmış ve buna bağlı olarak sosyal medya kullanımında da artış gözlenmiştir. Teknoloji kullanımında önemli düzeydeki 
artış, küçük yaş çocuklar için kritik bir noktayı göstermektedir. Amerikan Pediatri Akademisi, iki yaşın altındaki çocukların ekran başında asla kalmaması gerektiğini belirtmekte ve iki-beş yaş arasındaki çocuklar için bu süreyi bir saat aralığıyla sınırlandırmaktadır (Council on Communications and Media, 2016). Buna rağmen, bazı ebeveynlerin ve öğretmenlerin belirttiğine göre teknolojik araçlarla çok fazla ilgilenmeleri çocukların teknoloji bağımlıı̆ı ile sonuçlanmıştır (M1, M4, M8, M11, M12). Ancak bu süreçte teknoloji kullanımının yol açtığı bazı olumlu gelişmeler de ifade edilmiştir. Bu bakış açısına göre, bireylerin teknolojiye olan bakış açılarınının olumlu yönde değiştiği ve pandeminin eğitim teknolojilerinin kullanımına yönelik önemli katkılarının olduğu belirtilmiştir (M5, M11).

\section{Eğitsel Süreçler}

Pandeminin çocukların eğitsel süreçlerine yansımaları; öğrenme paydaşları, duyuşsal yaklaşım, öğrenme ve engeller bağlamında ortaya çıkmışıı. Öğrenme paydaşlarının başında öğretmenler gelmektedir. Pandemi sürecinde öğretmenlerle etkili iletişim kurulamaması, çocuğa verilen yetersiz geribildirim, öğretimde beden dilinin etkinliğinden yararlanılmaması (jest mimikler, ses tonu, fiziksel pekiştireç olarak temas) gibi unsurlar öğretmenlerin çocuklar üzerine etkisinde eğitsel bağlamda olumsuz yansımalara neden olmuştur. Okul öncesi ve sınıf öğretmenlerinin uzaktan öğretim süreçleriyle ilgili pandemi öncesinde deneyimlerinin olmadığı düşünüldüğünde, süreci olabildiğinde iyi yönettikleri ve ailelere bireysel olarak yönlendirmelerde bulunma çabası içinde oldukları da ifade edilmiştir.

Öğretmenler uzaktan eğitim sürecinde genellikle çocukların eğitsel faaliyetlerini günlük ödev ve etkinlikler gönderme, ders videoları gönderme, görüntülü ders yapma ve sosyal etkinlik duyuruları yapma yoluyla yürütmüşlerdir. Bunlara ek olarak, çocukların uzaktan öğretim sürecine ilişkin motivasyonlarının düşük olması, ilgilerinin çabuk dağılması ve ebeveynlerin bu süreçte çocuklarına yeterince destek olamaması, teknik altyapı sorunlarının olması, katılımın düşük olması gibi unsurların öğretmenlerin öğretme motivasyonunu da düşürdüğü belirtilmiştir (M7, M13, M18, M14, M15). Öğretmenin motivasyonu çocukların da öğrenmeye ilişkin motivasyonunu etkileyebilir. Bu nedenle çocukların eğitsel deneyimleri üzerinde doğrudan ve dolaylı etkileri bulunabilir.

Eğitsel süreçlerin diğer öğrenme paydaşı ise anne ve babalardır. Ebeveynlerin birçoğunun evde çocuklarıyla eğitsel faaliyetlerde bulunduğu, anne baba olma rolüne ek olarak öğretmen olma rolünü de üstlendikleri, bazı anne babaların çocukların eğitsel süreçlerini yakından takip ettikleri ifade edilmiştir. Bazı ebeveynler ise bu süreçte okulun önemini anladıklarını, okuldaki sosyalleşme imkânlarından çocukların mahrum kaldığını, uzaktan eğitimin zor ve yararsız olduğunu belirtmiştir. Bazı anne babalar ise süreçte çocuğun eğitimini takip etme konusunda ilgisiz kalmıştır (M11, M2, M3, M5).

Eğitsel süreç kategorisi altında ortaya çıkan diğer alt kategori ise öğrenmedir. Ele alınan çalışmaların öğrenmeye ilişkin bulguları incelendiğinde pandemi sürecinde uzaktan öğretimin tekrarlı anlatılmasının kalıcı öğrenmeler sağladığı, uzaktan eğitimin çocukların bireysel farklılıklarına ve farklı öğrenme tarzlarına uygun olduğu, akademik açıdan derslerden geri kalmamak adına önemli olduğu vurgulanmıştır. Öte yandan, uzaktan öğretim sürecinde derslere devamsızlık artış göstermiş ve temel akademik becerilerde (ilkokuma ve yazma) sıkıntılar yaşanmıştır. Çocukların kısa dikkat süresi nedeniyle çevrimiçi sürecine katılımlarının verimsiz olduğu, yüz yüze eğitime uyum sağlanamadığı ve çocukların uzaktan eğitim için gerekli çalışma disiplinine sahip olmadıkları ve hazırbulunuşluklarının yetersizliği vurgulanmıştır (M14, M5, M7, M9, M12, M11). 
Eğitsel süreçlere ilişkin çocukların duyuşsal yaklaşımlarına yönelik bulgular incelendiğinde; uzaktan eğitimde eğlenceli etkinliklere yer verilmesi sayesinde öğrenci motivasyonunun arttığı, çocuklarda sorumluluk duygusunun geliştiği, ev ortamında derslerin sürmesi sebebiyle çocukların rahatladığı, ailelerin teknolojiye bakış açılarının pozitif yönde etkilendiği ve çocukların değişime uyum sağladıkları görülmüştür. Ancak bazı bulgularda uzaktan eğitim sürecinde çocukların derse ilgisinin olmadığı, meraklarını canlı tutamadıkları belirtilmiştir (M14, M7, M9, M10, M11, M11).

Eğitsel süreci şekillendiren sonuncu önemli boyut ise engelleyici unsurlardır. Çalışmalarda en çok vurgulanan engelleyici unsurlar; altyapı (internet erişiminin olmaması, teknolojik altyapının olmaması), teknik (bilgisayar programları ve bilgisayar aksanıyla sorunlar, bağlantı kopukluğu ve bağlantı yavaşığı), içerik (derslerin ayrıntılı anlatılamaması, okul öncesi eğitime yönelik programların olmayışı, oyun temelli olmaması), katılım (öğrenci ilgisizliği, motivasyon düşüklüğü, derslerden soğuma, ders katılımının az olması, her öğrencinin internet üzerinden iletişim kuramaması), organizasyon (belirli zamanlarda olması), ev ortamından kaynaklı engeller (evde eğitim görmek istememe, velilerin teknoloji kullanma eksiği, ilgisiz ebeveynler, birden çok kardeşin aynı anda uzaktan eğitim alacak olması), ve fırsat ve imkan eşitsizliğidir (çocukların bilgisayarlarının ve internet bağlantılarının olmaması) (M3, M11, M15, M13, M14, M7, M18, M9, M15). Pandeminin ilerleyen sürecinde uzaktan eğitim süreçlerinin yüz yüze eğitimle birlikte yürütülmesi çocuklarda uyum sorunlarını gündeme getirmiştir. Öğretmenler, yüz yüze eğitimi daha verimli olarak değerlendirmiştir. Ancak çocuklar okula döndüğünde onları destekleyecek oyun gibi yöntemlerin geliştirilmesi de önemlidir. Nitekim çocukların sosyal ve duygusal refahına ve okula dönüşlerine destek olarak oyunun öğretmen yaklaşımları açısından önemi vurgulanmaktadır (O'Keeffe ve McNally, 2021; United Nations International Children's Emergency Fund [UNICEF], 2018).

Sonuç olarak, tüm dünyada ve yaşamın tüm alanlarında köklü değişimlere sebep olan pandemi, eğitim alanında da radikal değişimlere yol açmıştır. Yeni dünya düzenine uygun eğitimin yapılandırılabilmesi açısından eğitim teknolojileri, uzaktan eğitimde öğretim tasarımı, ölçme ve değerlendirme, dijital veriler ve etik, yeni eğitsel roller, dijital yeterlilikler ve dijital beceriler, dijital dönüşüm, dijital bölünme, sosyal eşitlik, travma ve kaygı, ilgi, anlayış ve empati pedagojisi, destek toplulukları ve mekanizmaları gibi unsurlarda reformlara gidilmesi gerekliliği açıkça görülmektedir (Bozkurt, 2020).

\section{Sınırlılıklar ve Güçlü Yönler}

Bu meta-sentez araştırmasının bazı sınırlııkları bulunmaktadır. Bunlardan ilki, incelemeye dâhil edilen araştırmaların sayısının az olmasıdır, bu durum bulguların genellenebilirliğini etkileyebilir. ikincisi, çalışmada bilişsel, fiziksel, duygusal, toplumsal ve eğitsel bağlamlar ele alınmıştır. Ancak çalışmaya dâhil edilen araştırmaların bağlamları incelendiğinde; incelenen her bir bağlamı karşılayan makale sayısı homojen bir dağılıma sahip değildir. Son olarak, belirlenen dâhil etme ölçütleri, ilgili bilgilerin kaybına neden olabilir.

Araştırmada yer alan sınırlılıklarla birlikte, bu araştırma, 0-8 yaş dönemindeki çocukların birincil bakım ve eğitim sorumluluğu taşıyan ebeveyn ve öğretmenlerin deneyimlerini sentezleyerek bir iç görü oluşturup mevcut alan yazını genişletmiştir. Bu inceleme, çocuklar için mevcut pandemi ve gelecekte olası halk sağlığı krizleri için daha iyi hazırlık yapmanın imkânını sağlayabilecek ve çocukların bedensel, ruhsal, duygusal, eğitsel ve toplumsal açıdan zarar görmelerini engelleyecek tedbirler için katkı getirebilir.

\section{Sonuç ve Öneriler}


Pandeminin erken çocukluk dönemine yansımalarını ebeveyn ve öğretmenlerin bakış açıları ile irdeleyen çalışmaların incelendiği bu meta-sentez araştırmasında, öncelikli olarak pandeminin çocukların bilişsel süreçlerine olan yansımaları ele alınmıştır. Çocukların yaş grubuna ve pandeminin kendilerine açıklanış biçimine bağı olarak pandemiyi anlamlandırmalarının farklılaştığı görülmüştür. Bu süreçte çocuklardaki fiziksel gelişim alanına bakıldığında; beslenme ve temizlik, spor ve hareket alışkanlıklarında ve buna bağlı olarak fiziksel görünümlerinde değişimler olduğu sonucuna ulaşılmıştır. Fiziksel görünümü ve sağlığı en çok tetikleyen unsurun ise ev ortamında daha çok pasif/oturarak yapılan etkinliklerin tercih edilmesi olduğu sonucuna ulaşılmıştır. Pandemi sürecinde çocukların duyuşsal durumları sıkıkla vurgulanmıştır. Bu bağlamda çocukların duygusal iyi oluşları sıklıkla vurgulanmıştır. Bazı çocukların duygusal durumları negatif yönde değişim göstermiş ve bu farklılı̆ı oluşturan temel unsurun çocukların sosyal ve duygusal ihtiyaçlarının ebeveynler tarafından farklı düzeylerde ve yöntemler ile karşılanması olduğu çıkarımına ulaşılmıştır. Çocuklar salgın sürecinde hissettikleri duyguları genellikle öfke, saldırganlık, hırçınlık gibi yollarla ifade etmiştir. Çocukların yaşadıkları bu duygusal süreçlerin yönetiminde ebeveynlerin bir kısmı baskıcı disiplin yöntemlerini kullanırken, bazı ebeveynler ise pozitif disiplin anlayışını benimsemiştir. Akran ilişkilerinin azalması, aile içi dinamiklerin gerek ekonomik gerek sosyal ve psikolojik bağlamda değişmesi, alınan izolasyon önlemleri neticesinde hissedilen sosyal mahrumiyet ve teknoloji kullanımındaki artış, pandemi sürecinde çocukların toplumsallaşma davranışlarının önemli unsurlarını oluşturmuştur. Son olarak öğrenme paydaşları olarak anne-babalar ve öğretmenlerin çocuklarla etkileşimleri, öğrenme sürecinin niteliği, öğrenmeye ilişkin çocukların duyuşsal yaklaşımlarını şekillendiren unsurlar ve öğrenme engelleri, çocukların eğitsel süreçlerinde önemli değişim ve dönüşümleri meydana getirmiştir. Özetle, pandemi çocukların yaşamlarına yeni gerçeklikler katmıştır. Bulgular, salgının etkilerine karşı sürdürülebilir çözümler üretilmesine yönelik duyulan gereksinimi göstermiştir. Bu kapsamda aşağıdaki öneriler getirilebilir:

Çocukların duygusal iyi oluşları üzerinde doğrudan etkili olan ebeveynlerin çocuklarla etkili iletişim kurma, çocuğun gelişimini bütüncül olarak destekleme, pozitif disiplin yöntemleri, ev ortamı kalitesinin artırılması gibi konularda bilinçlendirilmeleri gerekmektedir.

Pandemi sürecinde çocukların duygu durum sorunlarını önlemek için rehberlik servislerinin çocukları sistematik takip edecekleri ve ihtiyaç halinde psikolojik destek sağlayacakları birimlerin olması gerekmektedir.

Salgın sürecinde uzaktan öğretimin sürdürülebilir olması için, öğretim içerik ve materyallerinin çocukların öğrenme biçimine uygun hale getirilmesi, çocuklara yaparak-yaşayarak öğrenme deneyimleri sağlayabilmesi ve oyun temelli olması önem arz etmektedir.

Gelişim açısından çok kritik bir dönemde yer alan 0-8 yaş grubu çocuklarının ekrana maruz kalma sürelerinin minimum düzeyde tutularak uzaktan eğitim faaliyetlerinin sürdürülmesi ve pandemi şartlarına uygun özellikle motor-hareket becerilerini geliştirme fırsatları sunan fiziksel alanların oluşturulması gerekmektedir.

Eğitimciler, uzaktan öğrenme süreçleri ve öğretimsel yöntemler konusunda eğitilmeli ve erken çocukluk döneminde kullanılan teknolojilerle ilgili kaynakları takip etmelidir. Çocukların afet sonrası ruhsal durumlarıyla ilgili destekleyici bilgileri öğrenme konusunda kendilerini geliştirmelidir.

Son olarak, bu araştırmanın kapsamında ele alınmayan dezavantajlı ve özel eğitim gereksinimli çocuklara salgın sürecinin yansımalarını sentezleyen çalışmalar yapılabilir. Çocukların 
salgın sürecinde dayanıklılı̆ını arttıran mekanizmaların anlaşııması için boylamsal çalışmalar yürütülebilir. Erken çocukluk bağlamında uzaktan eğitimde motivasyonu ve öğrenmeyi güçlendiren etkili pedagojik yollar ve araçlar üzerinde çalışmalar yapılabilir.

\section{Kaynakça}

*Işaretli makaleler, bu araştırma kapsamında meta-sentez için ele alınan makaleleri ifade etmektedir.

*Akkaş-Baysal, E., Ocak, G. ve Ocak, İ. (2020). Covid-19 salgını sürecinde okul öncesi çocuklarının EBA ve diğer uzaktan eğitim faaliyetlerine ilişkin ebeveyn görüşleri. Uluslararası Sosyal Bilimler Eğitimi Dergisi, 6(2), 185-214.

*Alisinanoğlu, Karabulut, R ve F., Türksoy, E. (2020). Pandemi sürecinde çocukluk dönemi korkuları. Uluslararası Beşeri Bilimler ve Eğitim Dergisi, 6(14), 447-568.

*Aytaç, T. (2021). The problems faced by teachers in Turkey during the Covid-19 pandemic and their opinions. International Journal of Progressive Education, 17(1), 404-420. doi:10.29329/ijpe.2020.329.26

*Balaman, F. ve Hanbay-Tiryaki, S. (2021). Corona virüs (Covid-19) nedeniyle mecburi yürütülen uzaktan eğitim hakkında öğretmen görüşleri. Insan ve Toplum Bilimleri Araştırmaları Dergisi, 10(1), 52-84.

Barlett, J. D., Griffin, J. ve Thomson, D. (2020, 19 March). Resources for supporting children's emotional wellbeing during the Covid-19 pandemic. Child Trends. Erişim adresi (1, Haziran, 2021): https://www.childtrends.org/publications/resources-for-supporting-childrens-emotional-well-beingduring-the-covid-19-pandemic

Başaran, M., ve Aksoy, A. B. (2020). Parents' views on the family lives in the coronavirus (COVID-19) outbreak process. The Journal of International Social Research, 13(71), 668-678.

Bozkurt, A. (2020). Koronavirüs (Covid-19) pandemi süreci ve pandemi sonrası dünyada eğitime yönelik değerlendirmeler: Yeni normal ve yeni eğitim paradigması. Açıköğretim Uygulamaları ve Araştırmaları Dergisi, 6(3), 112-142.

Bozkurt, Y, Zeybek, Z ve Aşkın, R. (2020). Covid-19 pandemisi: Psikolojik etkileri ve terapötik müdahaleler. istanbul Ticaret Üniversitesi Sosyal Bilimler Dergisi, Bahar (Covid19-Özel Ek), 304-318.

Brown, S. M., Doom, J., Watamura, S., Lechuga-Pena, S. ve Koppels, T. (2020). Stress and parenting during the global COVID-19 pandemic. Child abuse \& neglect, 110(Pt 2), 104699. doi:10.1016/j.chiabu.2020.104699

Cachón-Zagalaz, J., Zagalaz-Sánchez, M. L., Arufe-Giráldez, V., Sanmiguel-Rodríguez, A. ve González-Valero, G. (2021). Physical activity and daily routine among children aged 0-12 during the covid-19 pandemic in Spain. Int. J. Environ. Res. Public Health, 18, 703. doi:10.3390/ ijerph18020703

*Cakin, M. ve Kulekci-Akyavuz, E. (2021). Educational adventure of students in the COVID-19 period in Turkey: Determination of parents' views. International Journal on Social and Education Sciences (IJonSES), 3(1), 109-125. doi:10.46328/ijonses.87

Campbell, A. M. (2020). An increasing risk of family violence during the Covid-19 pandemic: Strengthening community collaborations to save lives. Forensic Science International Reports, 2, 100089. doi:10.1016/j.fsir.2020.100089

Chung, G., Lanier, P. ve Wong, P. Y. J. (2020). Mediating effects of parental stress on harsh parenting and parent-child relationship during coronavirus (COVID-19) pandemic in Singapore. Journal of Family Violence, 1-12. doi:10.1007/s10896-020-00200-1

Council on Communications and Media. (2016). Media and young minds. Pediatrics, 138(5), e20162591. doi:10.1542/peds.2016-2591

Çağdaş, A. ve Şahin-Seçer, Z. (2015). Anne-baba eğitimi. Ankara: Eğiten Kitap.

Çiçek, B. ve Almalı, V. (2020). COVID-19 pandemisi sürecinde kaygı öz-yeterlilik ve psikolojik iyi oluş arasındaki ilişki: Özel sektör ve kamu çalışanları karşılaştırması. Electronic Turkish Studies, 15(4), $\quad$ 241-260. doi:10.7827/TurkishStudies.43492

Clemmens, D. (2003). Adolescent motherhood: A meta-synthesis of qualitative studies. MCN: The American Journal of Maternal/Child Nursing, 28(2), 93-99. doi:10.1097/00005721-200303000-00010 
Dayal, H. C. ve Tiko, L. (2020). When are we going to have the real school? A case study of early childhood education and care teachers' experiences surrounding education during the COVID-19 pandemic. Australasian Journal of Early Childhood, 45(4), 336-347. doi:10.1177/1836939120966085

*Demir, F., ve Özdaş, F. (2020). Covid-19 sürecindeki uzaktan eğitime ilişkin öğretmen görüşlerinin incelenmesi. Milli Eğitim Dergisi, 49(1), 273-292.

*Demir-Öztürk, E., Kuru, G. ve Demir-Yıldız, C. (2020). Covid-19 pandemi günlerinde anneler ne düşünür çocuklar ne ister? Anne ve çocuklarinin pandemi algısı. Avrasya Sosyal ve Ekonomi Araştırmaları Dergisi, 7(5), 204-220.

Dias, M. J., Almodóvar, M., Atiles, J. T., Vargas, A. C. ve Zúñiga León, I. M. (2020). Rising to the Challenge: Innovative early childhood teachers adapt to the COVID-19 era. Childhood Education, 96(6), 38-45. doi: 10.1080/00094056.2020.1846385

Dunton, G. F., Do, B. ve Wang, S. D. (2020). Early effects of the COVID-19 pandemic on physical activity and sedentary behavior in children living in the US. BMC Public Health, 20(1), 1-13. doi:10.1186/s12889020-09429-3

Ecclestone, K. (2012). From emotional and psychological well-being to character education: challenging policy discourses of behavioural science and 'vulnerability'. Research Papers in Education, 27(4), 463-480. doi: 10.1080/02671522.2012.690241

*Erol, M. ve Erol, A. (2020). Koronavirüs pandemisi sürecinde ebeveynleri gözünden ilkokul öğrencileri. Milli Eğitim Dergisi, 49(1), s. 529-551.

Ersan, C. (2017). Okul öncesi dönem çocuklarının saldırganlık düzeylerinin duygu ifade etme ve duygu düzenleme açısından incelenmesi (Yayımlanmamış doktora tezi). Pamukkale Üniversitesi, Eğitim Bilimleri Enstitüsü, Pamukkale.

Eyler A, Nanney M. S., Brownson, R. C., Lohman D ve Haire-Joshu D. (2006). Correlates of after-school activity preference in children ages 5-12: The PARADE study. Am J Health Educ., 37(2), 69-77. doi:10.1080/19325037.2006.10598882

Fan, Y., Wang, H., Wu, Q., Zhou, X., Zhou, Y., Wang, B., Han, Y., Xue, T. ve Zhu, T. (2020). SARS pandemic exposure impaired early childhood development: A lesson for COVID-19. [preprint] medRxiv. doi:10.1101/2020.05.12.20099945

*Fidan, M. (2020). Covid-19 Belirsizliğinde eğitim: ilkokulda zorunlu uzaktan eğitime ilişkin öğretmen görüşleri. Uşak Üniversitesi Eğitim Araştırmaları Dergisi, 6(2), 24-43.

France, E. F., Cunningham, M., Ring, N. ve diğerleri. (2019). Improving reporting of meta-ethnography: The eMERGe reporting guidance. Journal of Advanced Nursing, 75(5), 1126-1139. doi:10.1111/jan.13809

Greszler, R. ve Burke, L. M. (2020, 30 September). Rethinking early childhood education and childcare in the COVID-19 Era [Report]. Backgrounder. No. 3533. Heritage Foundation. Erişim adresi: https://files.eric.ed.gov/fulltext/ED609729.pdf

Gromada, A., Richardson, D. ve Rees, G. (2020). Childcare in a global crisis: The impact of COVID-19 on work and family life [Innocenti Research Briefs no. 2020-18]. Florence: UNICEF Office of Research-Innocenti. doi:10.18356/16d757a1-en

Group, U. (Ed.). (2020). The impact of COVID-19 on children. United Nations: New York. Erişim adresi: https://unsdg.un.org/resources/policy-brief-impact-covid-19-children

Gudbjartsson, D. F., Helgason, A., Jonsson, H., Magnusson, O. T., Melsted, P., Gudmundur L. N., Saemundsdottir, J., ve diğerleri. (2020). Spread of SARS-CoV-2 in the Icelandic population. New England Journal of Medicine, 382, 2302-2315. doi:10.1056/NEJMoa2006100

Hinkley, T., Brown, H., Carson, V. ve Teychenne, M. (2018). Cross sectional associations of screen time and outdoor play with social skills in preschool children. PLoS ONE, 13(4), e0193700. doi:10.1371/journal.pone.0193700

*Inan, H. Z. (2021). Challenges of distance/online and face-to-face education in the new normal: Experiences of Reggio Emilia-inspired early childhood educators in Turkey. Pedagogical Research,6(1), em0086. doi:10.29333/pr/9304

Jones, D. (2020). The impact of covid-19 on young children, families, and teachers. Defending the Early Years: Jamaica Plain, MA, USA. [Report], 1-13. ERIC Number: ED609168. Erişim adresi (1, Haziran, 2021): https://dey.org/wp-content/uploads/2020/09/The-Impact-of-COVID-19-on-Young-Children-Familiesand-Teachers-A-DEY-Report-9-8-20-FINAL.pdf 
*Karabudak, M. G. (2020). Opinions of 1st grade teachers on distance education adaptation process during the Covid 19 pandemic period. Social Scientific Centered Issues, 2(2), 72-80.

Keyes, C. L. M. (2002). The mental health continuum: From languishing to flourishing in life. Journal of Health and Social Research, 43(2), 207-222. PMID: 12096700.

Kim, J. (2020). Learning and teaching online during Covid-19: Experiences of student teachers in an early childhood education practicum. International Journal of Early Childhood, 52(2), 145-158. doi:10.1007/s13158-020-00272-6

Kol, S. (2011). Erken çocuklukta bilişsel gelişim ve dil gelişimi. Sakarya Üniversitesi Eğitim Fakültesi Dergisi, 21, 1-21.

*Kurt-Demirbaş, N. ve Sevgili-Koçak, S. (2020). 2-6 yaş arasında çocuğu olan ebeveynlerin bakiş açisiyla Covid19 salgın sürecinin değerlendirilmesi. Avrasya Sosyal ve Ekonomi Araştırmaları Dergisi, 7(6), 328-349.

Lee, I. F. (2020). Crisis of care and education in the early years: Paradoxical moments in the global pandemic. Global Studies of Childhood, 10(4), 385-394. doi:10.1177/2043610620978491

Long, H. (2020, 3 July). The big factor holding back the US economic recovery: Child Care [News comment]. The Washington Post. Erişim adresi: https://www.washingtonpost.com/business/2020/07/03/big-factorholding-back-us-economic-recovery-child-care/

Miller, J. G. (1994). Cultural diversity in the morality of caring: Individual-oriented versus duty-oriented interpersonal codes. Cross-Cultural Research, 28(1), 3-39. doi:10.1177/106939719402800101

Moher, D., Liberati, A., Tetzlaff, J. ve Altman, D. G. (2009). Preferred reporting items for systematic reviews and meta-analyses: The PRISMA statement. PLoS Med, 6(7): e1000097. doi:10.1371/ journal.pmed.1000097

Morgül, E., Kallitsoglou, A. ve Essau, C. A. (2020). Psychological effects of the COVID-19 lockdown on children and families in the UK. Revista de Psicología Clínica con Niños y Adolescentes, 7(3), 42-48. doi: 10.21134/rpcna.2020.mon.2049

O'Keeffe, C. ve McNally, S. (2021). 'Uncharted territory': Teachers' perspectives on play in early childhood classrooms in Ireland during the pandemic, European Early Childhood Education Research Journal, 29(1), 79-95. doi:10.1080/1350293X.2021.1872668

Park, E., Logan, H., Zhang, L., Kamigaichi, N. ve Kulapichitr, U. (2020). Responses to coronavirus pandemic in early childhood services across five countries in the Asia-pacific region: OMEP policy forum. International Journal of Early Childhood, 25, 1-18. doi:10.1007/s13158-020-00278-0

Polat, S. ve Ay, O. (2016). Meta-sentez: Kavramsal bir çözümleme. Eğitimde Nitel Araştırmalar Dergisi, 4(1), 52-64. doi:10.14689/issn.2148-2624.1.4c2s3m

Ryan, R. M. ve Deci, E. L. (2017). Self-determination theory: Basic psychological needs in motivation, development, and wellness. NY \& London: The Guilford Press. doi:10.1521/978.14625/28806

Samuelsson, I. P., Wagner, J. T. ve $\emptyset$ degaard, E. E. (2020). The coronavirus pandemic and lessons learned in preschools in Norway, Sweden and the United States: OMEP policy forum. International Journal of Early Childhood, 52(2), 129-144. doi:10.1007/s13158-020-00267-3

Saylık, F. Z. ve Yalçın, M. G. (2018). Otoriter veya demokratik ebeveyn tutumunun ve ebeveyne bağlanma biçiminin suçluluk ve utanç duygularına etkisinin yarı-deneysel yöntemle incelenmesi. Psikoloji Çalışmaları, 38(2), 95-127. doi:10.26650/SP404167.

Schreiber, R., Crooks, D. ve Stern, P. N. (1997). Qualitative meta-analysis. J. M. Morse (Ed.), Completing a qualitative project (s. 311-326) içinde. Thousand Oaks, CA: Sage.

Şahbudak, B. ve Emiroğlu, N. I. (2020). Çocuk ve ergende Covid-19 salgını ve duygudurum bozuklukları birlikteliği. Çocuk ve Gençlik Ruh Sağlığı Dergisi, 27(2), 59-63. doi:10.4274/tjcamh.galenos.2020.55265

Tarkoçin, S., Alagöz, N. ve Boğa, E. (2020). Okul öncesi dönem çocuklarının pandemi sürecinde (Covid-19) davranış değişiklikleri ve farkındalık düzeylerinin anne görüşlerine başvurularak incelenmesi. Electronic Turkish Studies, 15(6). elSSN:1308-2140. doi: 10.7827/TurkishStudies.44338

*Toran, M., Sak, R., Xu, Y., Şahin-Sak, I. T. ve Yu, Y. (2021). Parents and children during the COVID-19 quarantine process: Experiences from Turkey and China. Journal of Early Childhood Research, 19(1), 2139. doi:10.1177/1476718X20977583

United Nations International Children's Emergency Fund [UNICEF]. (2018, October). Learning through play: Strengthening learning through play in early childhood programs [Brief Report]. New York: UNICEF. Erişim adresi (1, Haziran, 2021): https://www.unicef.org/sites/default/files/2018-12/UNICEF-LegoFoundation-Learning-through-Play.pdf 
Usher, K., Bhullar, N. ve Jackson, D. (2020). Life in the pandemic: Social isolation and mental health. Journal of Clinical Nursing. 29(15-16), 2756-2757. doi:10.1111/jocn.15290

Weisner, T. S. (2010). Well-being, chaos, and culture: Sustaining a meaningful daily routine. G. W. Evans ve T. D. Wachs (Ed.), Decade of behavior (science conference). Chaos and its influence on children's development: An ecological perspective (s. 211-224) içinde. Washington: American Psychological Association.

World Health Organization [WHO]. (2020, March 11). WHO Director-General's opening remarks at the media briefing on COVID-19-11 March [News comment]. Erişim adresi (1, Haziran, 2021): https://www.who.int/director-general/speeches/detail/who-director-general-s-opening-remarks-atthe-media-briefing-on-covid-19---11-march-2020

Yoshikawa, H., Wuermli, A. J., Britto, P. R., Dreyer, B., Leckman, J. F., Lye, S. J., Ponguta, L. A., Richter, L. M. ve Stein, A. (2020). Effects of the global coronavirus disease-2019 pandemic on early childhood development: Short-and long-term risks and mitigating program and policy actions. The Journal of Pediatrics, 223, 188-193. doi:10.1016/j.jpeds.2020.05.020

Yucesoy-Özkan, S., Kaya, F., Gülboy, E., Altun, D. E. ve Oncul, N. (2020). General and special education practices during the COVID-19 viral outbreak in Turkey. I. Sahin ve M. Shelley (Ed.), Educational practices during the COVID-19 viral outbreak: International perspectives (s. 19-62) içinde. ISTES Organization.

*Yüksek-Usta, S., Gökcan, H. N. (2020). Covid-19 through the eye of children and mothers. International Journal of Social Sciences and Education Research, 6(2), 187-206.

*Yurtbakan, E. ve Akyıldız, S. (2020). Sınıf öğretmenleri, ilkokul öğrencileri ve ebeveynlerin Covid-19 izolasyon döneminde uygulanan uzaktan eğitim faaliyetleri hakkındaki görüşleri. Turkish Studies, 15(6), 949-977. doi:10.7827/TurkishStudies.43780

Zhao, Y., Guo, Y., Xiao, Y., Zhu, R., Sun, W., Huang, W., Liang, D., Tang, L., Zhang, F., Zhu, D. ve Wu, J. (2020). The effects of online homeschooling on children, parents, and teachers of grades 1-9 during the COVID-19 pandemic. Medical science monitor: International medical journal of experimental and clinical research, 26, e925591-1. doi:10.12659/MSM.925591 